\title{
Sequence-dependent Guest Release Triggered by Orthogonal Chemical Signals
}

\author{
Ana M. Castilla, Tanya K. Ronson, and Jonathan R. Nitschke* \\ Department of Chemistry, University of Cambridge, Lensfield Road, Cambridge CB2 1EW, United Kingdom \\ Supporting Information Placeholder
}

\begin{abstract}
Three $\mathrm{Zn}_{4}{ }_{4} \mathrm{~L}_{4}$ coordination cages, assembled from tris-iminopyridine ligands, exhibit differences in their guest-binding selectivities and reactivity with tris(2-aminoethyl)amine (tren), which enabled the design of a molecular network that responded in distinct ways to different chemical signals. When two of these cages were present in solution together, one of them was observed to selectively encapsulate chloroform, and the other, cyclohexane. The two guests could be released sequentially, in a specified order defined by the input of two separate chemical signals: tren and perrhenate. Furthermore, the observed reactivity of tren with the initial cage mixture provided control over the uptake and release of perrhenate within the third cage formed in situ. One of these tetrahedral cages has been identified as a tight $\left(K_{\mathrm{a}}>10^{7} \mathrm{M}^{-1}\right)$ and selective host for perrhenate, an anion of great physicochemical similarity to pertechnetate, both having uses in nuclear medicine.
\end{abstract}

\section{Introduction}

Increasingly fine control over the processes and outcomes of chemical self-assembly has enabled the development, in recent years, of complex chemical systems with useful functions that emerge from the collectivity of their individual components. ${ }^{1,2}$ In order to shape these functions, studies have been carried out into designing molecular networks and elucidating how they behave in response to stimuli. ${ }^{3}$ These synthetic chemical networks enable the design of materials able to adapt their properties to changes in the environment. ${ }^{3 a-}$ g,4 Advances in this area require gaining control over systems in which different stimuli trigger independent and distinct responses, allowing different behavior to be engendered. ${ }^{5,6}$ Selective sequences of stimuli have been employed to determine the direction of travel of a molecular walker ${ }^{5 b}$ or the successive release of cargos from silica nanoparticles. ${ }^{5 \mathrm{c}}$

The well-defined inner phases of self-assembled metalorganic polyhedra ${ }^{7,8}$ have proven useful in a diverse range of applications, ${ }^{9}$ from molecular recognition and sensing ${ }^{8 \mathrm{a}, 10}$ to gas sequestration, ${ }^{11}$ stabilization of reactive species ${ }^{12}$ and catalysis. ${ }^{13}$ These hosts are excellent candidates for incorporation into molecular networks to explore complex and stimuli-responsive behaviors ${ }^{14,15}$ due to their encapsulation abilities and the dynamic nature of the linkages that hold them together. Investigating systems that comprise multiple hosts and guests together may allow for new functions to be designed, beyond what is achievable with single host-guest systems. ${ }^{14 \mathrm{a}, 15 \mathrm{c}, 16}$

Here we describe a system composed of self-assembled cages that has been designed to exhibit complex guest release behavior in response to two distinct chemical signals. These are a competing guest and a reagent, tren, which effects a host transformation. In addition, we demonstrate the system's overall response to be dependent on the sequence of applied stimuli, a property that is not characteristic of any one cage structure, but which emerges from the system. This sequence dependent response confers a further level of complexity on the system, which would not be attainable by a simple collection of two receptors that bind two different guests, where release can be triggered by the addition of other competing guests for example.

\section{Results and Discussion}

To design this system, we selected three face-capped ${ }^{17}$ $\mathrm{Zn}^{\mathrm{II}}{ }_{4} \mathrm{~L}_{4}$ tetrahedral capsules, in which tritopic iminopyridine ligands are formed from either a phenyl-centered trisaniline $^{16 c, 17 a}$ or a phenyl-centered tris-formylpyridine. ${ }^{18} \mathrm{~A}$ detailed study allowed us to identify two key features for the implementation of a stimuli-responsive molecular network: First, contrasting guest binding preferences and affinities, and second, orthogonal reactivities of the tris-aniline and trisformylpyridine based structures with tris(2-aminoethyl)amine (tren). Consideration of these features led to the design of the network depicted in Scheme 1. Two different neutral guests, cyclohexane and chloroform were each selectively encapsulated in one of the two $\mathrm{Zn}_{4}^{\mathrm{II}} \mathrm{L}_{4}$ hosts $(\mathbf{1}$ - 2). Each guest could be selectively released using one of two distinct chemical signals: treatment with tren released cyclohexane, and addition of perrhenate liberated chloroform. Reversing the order of the signals reversed the order of guest release. Intriguingly, whereas one signaling pattern (sequence I) resulted in complete destruction of the cages and ultimately ejection of perrhenate into solution, the reverse pattern (sequence II) allowed perrhenate to be trapped within a stable host (3) formed at the end of the sequence. 
The design of this network is grounded upon systematic investigations of the guest binding properties of hosts 1-3 (Scheme 1), which also revealed the unprecedented affinity of new hosts 2 - 3 for perrhenate. ${ }^{19,20}$ This anion is relevant as a surrogate in the design of receptors for radioactive pertechnetate, and also to applications in nuclear medicine; the development of selective perrhenate and pertechnetate receptors has proven particularly challenging. ${ }^{19,21}$ Furthermore, the significant differences in anion uptake kinetics were uncovered between tris-formylpyridine-based cages $\mathbf{2}$ and $\mathbf{3}$, whose vertices are capped with three toluidine residues or one tren, respectively. These differences provided insight into the guest uptake and exchange mechanisms ${ }^{22}$ of the face-capped tetrahedra described herein.

\section{Scheme 1. Sequence-Selective Release of Guests Triggered by Orthogonal Chemical Signals. ${ }^{a}$}
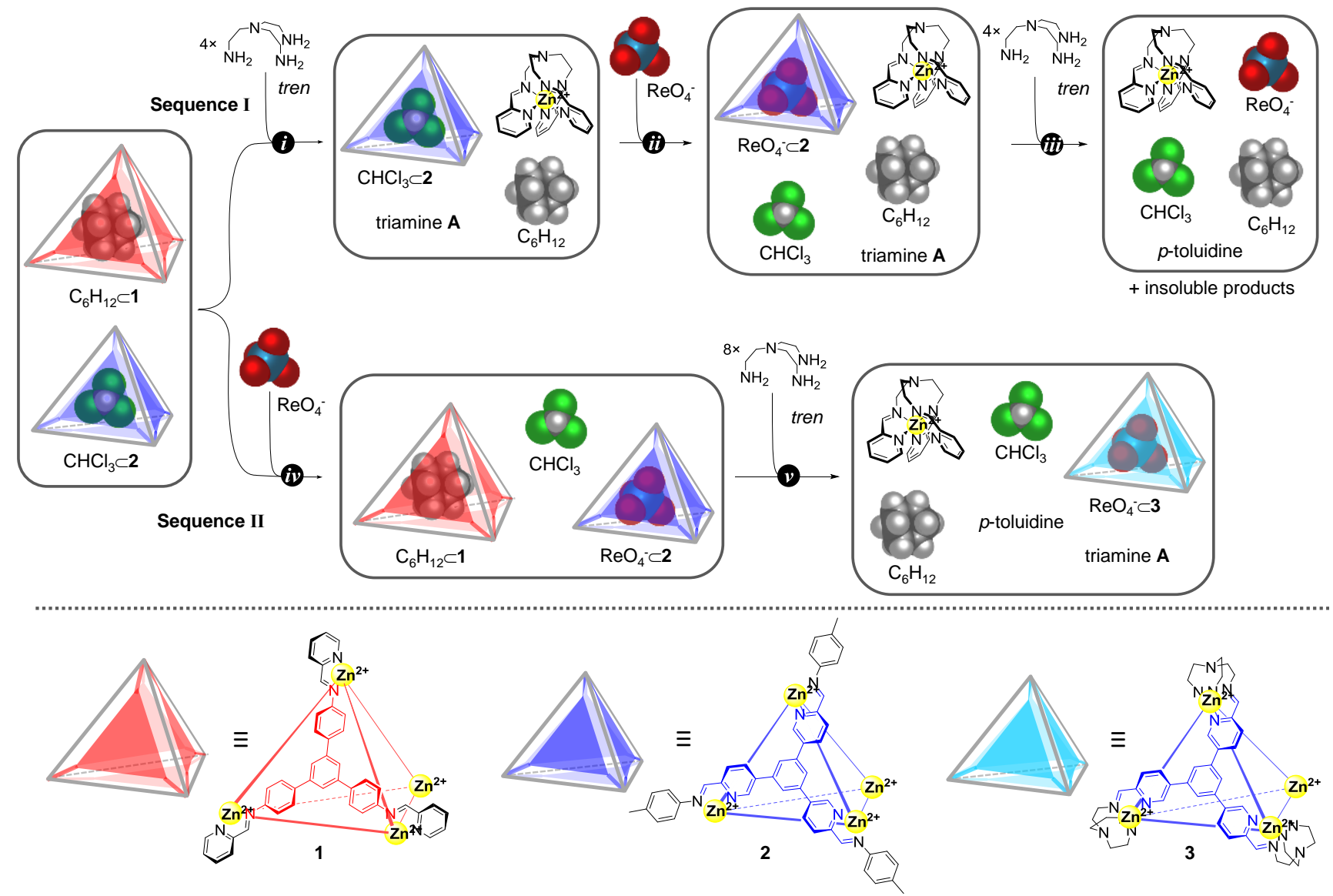

${ }^{a}$ Signal Sequence I: $i$ ) disassembly of $\mathbf{1}$ and release of $\left.\mathrm{C}_{6} \mathrm{H}_{12} ; i i\right)$ release of $\mathrm{CHCl}_{3}$ by displacement with $\mathrm{ReO}_{4}{ }^{-}$from the cavity of $\mathbf{2}$; iii) release of $\mathrm{ReO}_{4}^{-}$upon disassembly of $\mathbf{2}$. Signal sequence II: $i v$ ) release of $\mathrm{CHCl}_{3}$ by displacement with $\mathrm{ReO}_{4}{ }^{-}$from the cavity of $2 ; v$ ) simultaneous breakdown of $\mathbf{1}$ releasing $\mathrm{C}_{6} \mathrm{H}_{12}$ and transformation of $\mathbf{2}$ into $\mathbf{3}$ while maintaining sequestration of $\mathrm{ReO}_{4}^{-}$. $\mathbf{A}$ and $\mathbf{B}$ denote the face-capping subcomponents 1,3,5-tris(4'-aminophenyl)benzene (for cage 1) and 1,3,5-tris(2'-formylpyridyl5')benzene (for cages 2 - 3). N.B. The insoluble products in Sequence I contain triamine A and trialdehyde B.

Synthesis and characterization of cages 1-3. Tetrahedra 1-3 (Scheme 2) self-assembled from zinc(II) and tritopic subcomponents: either 1,3,5-tris(4'aminophenyl)benzene, $\mathbf{A}^{17 \mathrm{a}}$ (cage 1) or 1,3,5-tris(2'formylpyridyl-5')benzene, $\mathbf{B}^{18}$ (cages $\mathbf{2}$ and $\mathbf{3}$ ). The synthesis if $\mathbf{1}$ has been previously described. ${ }^{16 \mathrm{c}}$ The reaction of $\mathbf{B}, p$ toluidine and zinc(II) bis(trifluoromethylsulfonyl)imide (triflimide, $\mathrm{NTf}_{2}{ }^{-}$) in a 1:3:1 ratio in acetonitrile afforded 2, isolable as a greenish crystalline solid. Vapor diffusion of diethyl ether into an acetonitrile solution of $\mathbf{2}$ produced crystals suitable for analysis by single-crystal X-ray diffraction (Figure 1). The four facially coordinated $\mathrm{Zn}^{\text {II }}$ centers are bridged by four face-capping ligands, resulting in a tetrahedral arrangement with approximate $T$-symmetry. All
$\mathrm{Zn}^{\mathrm{II}}$ stereocenters within a cage share the same $\Delta$ or $\Lambda$ stereochemistry; both cage enantiomers are present in the crystal. The cavity of $\mathbf{2}$ is almost completely enclosed by the ligands, with pores of less than $1.3 \AA$ in diameter. The $\mathrm{Zn}-\mathrm{Zn}$ distances are in the range 11.278(4)-11.774(3) $\AA$ (average 11.5 $\AA$ ) and the cavity volume was calculated to be $130 \AA^{3}$ using VOIDOO (see section 7 in the Supporting Information). ${ }^{23}$

Similarly, the reaction in acetonitrile/methanol (1:1) of $\mathbf{B}$, tren and $\mathrm{Zn}\left(\mathrm{NTf}_{2}\right)_{2}$ in a 1:1:1 ratio generated tetrahedral cage $\mathbf{3}$, isolable as a yellowish crystalline solid. The single-crystal structure of $\mathbf{3}$ (Figure 1) closely resembles that of $\mathbf{2}$, except that tren residues cap the vertices of the tetrahedron, forming an extended cryptand-like architecture. The $\mathrm{Zn}-\mathrm{Zn}$ distances of 11.749(3)-11.775(3) $\AA$ fall within the range observed for 2 ; 
the average distance is $11.8 \AA$. The cavity volume was calculated to be $111 \AA^{3}$, marginally smaller than 2 due to the faces of $\mathbf{3}$ pressing inward slightly relative to those of $\mathbf{2}$ (see section 7 in the SI). The use of a smaller tris-formylpyridine based ligand thus leads to cages that enclose less volume than cage 1 ( $\mathrm{Zn}-\mathrm{Zn}$ distance $14.6 \AA$, volume $\left.188 \AA^{3}\right)$, formed from the analogous tris-aniline subcomponent $\mathbf{A}$ (Figure 1). ${ }^{16 \mathrm{c}}$

Scheme 2. Subcomponent Self-Assembly of cages 1 - 3 and the transformation of 2 into 3 . $^{a}$

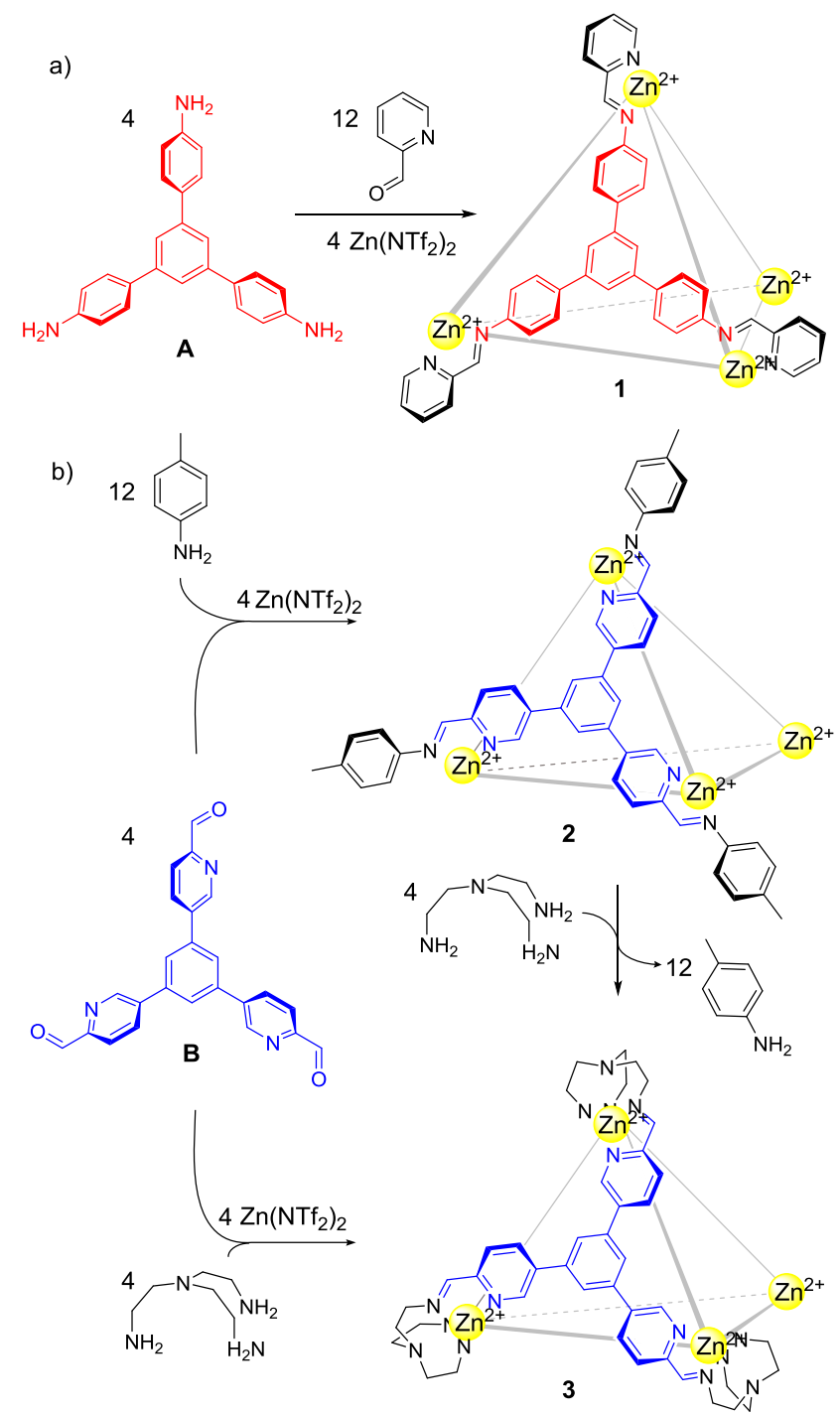

${ }^{a}$ Only one ligand is drawn per structure for clarity.

ESI-MS and NMR analyses reflect solution structures of 2 and $\mathbf{3}$ analogous to what is observed in the solid state. Their simple ${ }^{1} \mathrm{H}$ NMR spectra, with only one set of ligand resonances, are consistent with the formation of a single diastereomer with $T$ point symmetry. Their ${ }^{19} \mathrm{~F}$ NMR spectra, with only one sharp signal having a chemical shift corresponding to unencapsulated $\mathrm{NTf}_{2}^{-}$, confirmed that the cages do not bind this anion in solution (Figures S3 - S4). Triflimide was, indeed, chosen specifically to avoid counterion encapsulation, in order to facilitate host-guest studies. ${ }^{10 \mathrm{a}}$ Considering the volumes of their $\mathrm{Fe}^{\mathrm{II}}$-templated analogs, ${ }^{18}$ we anticipated that $\operatorname{NTf}_{2}^{-}\left(157 \AA^{3}\right)$ would be too voluminous to fit in the cavity of cages $\mathbf{2}$ and 3 . $^{10 \mathrm{a}}$

In similar fashion to their $\mathrm{Fe}^{\mathrm{II}}$-containing congeners, ${ }^{18}$ cage 3 could also be prepared through substitution of the twelve $p$ toluidine residues incorporated into the periphery of cage 2 with four equivalents of tren (Scheme 2). The treatment of a solution of cage 2 in acetonitrile with 4.5 equivalents of tren at $70{ }^{\circ} \mathrm{C}$ afforded cage 3 as the only product observed by ${ }^{1} \mathrm{H}$ NMR and ESI-MS (see section 4.4 in the SI). We infer this imine exchange reaction to be driven by the more electron-rich character of tren and the chelate effect.

Cage 2 was also prepared from the zinc(II) salts of tetrafluoroborate $\left(\mathbf{2} \cdot\left[\mathrm{BF}_{4}\right]_{8}\right)$, perchlorate $\left(\mathbf{2} \cdot\left[\mathrm{ClO}_{4}\right]_{8}\right)$ and triflate $\left(\mathbf{2} \cdot[\mathrm{OTf}]_{8}\right)$. Similarly $\mathbf{3} \cdot[\mathrm{OTf}]_{8}$ was obtained from $\mathrm{Zn}(\mathrm{OTf})_{2}$ in a $\mathrm{CH}_{3} \mathrm{CN} / \mathrm{CH}_{3} \mathrm{OH}$ mixture. In contrast, attempts to form cage 3 from $\mathrm{Zn}\left(\mathrm{BF}_{4}\right)_{2}$ or $\mathrm{Zn}\left(\mathrm{ClO}_{4}\right)_{2}$ resulted in insoluble products. Cage $3 \cdot\left[\mathrm{BF}_{4}\right]_{8}$ could, however, be prepared through reaction of $\mathbf{2} \cdot\left[\mathrm{BF}_{4}\right]_{8}$ with tren, whereas analogous reactions with $\mathbf{2} \cdot\left[\mathrm{ClO}_{4}\right]_{8}$ and $\mathbf{2} \cdot[\mathrm{OTf}]_{8}$ afforded intractable precipitates.

Anion binding studies. The anion encapsulation abilities of cages $\mathbf{2}$ and $\mathbf{3}$ were probed by treating them in solution with a series of anions having different shapes and volumes (listed in tables S2 and S6 in the Supporting Information). Previous studies determined that tetrahedron 1 does not bind anions in its cavity. ${ }^{16 c, 17 a}$ Cage 2 was observed to bind the anions (in order of size) $\mathrm{NO}_{3}^{-}, \mathrm{BF}_{4}^{-}, \mathrm{ClO}_{4}^{-}, \mathrm{ReO}_{4}^{-}$, $\mathrm{PF}_{6}^{-}, \mathrm{SbF}_{6}^{-}$and $\mathrm{TfO}^{-}$, as confirmed by ${ }^{1} \mathrm{H}$ and ${ }^{19} \mathrm{~F}$ NMR. The addition of the tetrabutylammonium salt of $\mathrm{ClO}_{4}^{-}, \mathrm{ReO}_{4}^{-}, \mathrm{PF}_{6}^{-}$ or $\mathrm{TfO}^{-}$, or the potassium salt of $\mathrm{SbF}_{6}^{-}$(0.5 equiv) to a solution of $2 \cdot\left[\mathrm{NTf}_{2}\right]_{8}$ resulted in the appearance of a new set of ${ }^{1} \mathrm{H}$ NMR signals, assigned to the inclusion complexes in slow exchange with the free cage on the NMR timescale (Figure S12). Solutions containing $\mathrm{PF}_{6}^{-}$or $\mathrm{TfO}^{-}$each showed two new ${ }^{19} \mathrm{~F}$ NMR signals (in addition to the $\mathrm{NTf}_{2}^{-}$resonance) attributed to free and encapsulated anions (Figures S8 and $\mathrm{S} 15)$. The ${ }^{19} \mathrm{~F}$ NMR spectrum of the solution containing $\mathrm{SbF}_{6}$ showed a broadened, extended multiplet assigned to this anion due to overlapping signals of free and encapsulated species.

In contrast, the addition of tetrabutylammonium salts of the smaller anions $\mathrm{BF}_{4}^{-}$or $\mathrm{NO}_{3}^{-}$to a solution of 'empty' 2 , provided evidence for anion binding in fast exchange. The ${ }^{1} \mathrm{H}$ NMR signals of the host were observed to shift, with the resonances due to the central phenyl and inward-facing pyridine protons undergoing the greatest shifts (Figure S12). In the case of $\mathrm{BF}_{4}^{-}$, broadening of the ${ }^{1} \mathrm{H}$ and ${ }^{19} \mathrm{~F}$ NMR spectra was also observed. Encapsulation of $\mathrm{BF}_{4}^{-}$was further supported by a ${ }^{1} \mathrm{H}-{ }^{19} \mathrm{~F}$ HOESY spectrum, in which correlations were observed between the anion resonance and signals corresponding to the protons of the ligand pointing towards the inside of the cavity (Figure S18). Other anions screened, such as $\mathrm{Cl}^{-}, \mathrm{Br}^{-}$or $\Gamma$, gave rise to a color change and precipitation following their addition to a solution of $\mathbf{2} \cdot\left[\mathrm{NTf}_{2}\right]_{8}$, consistent with cage decomposition. 

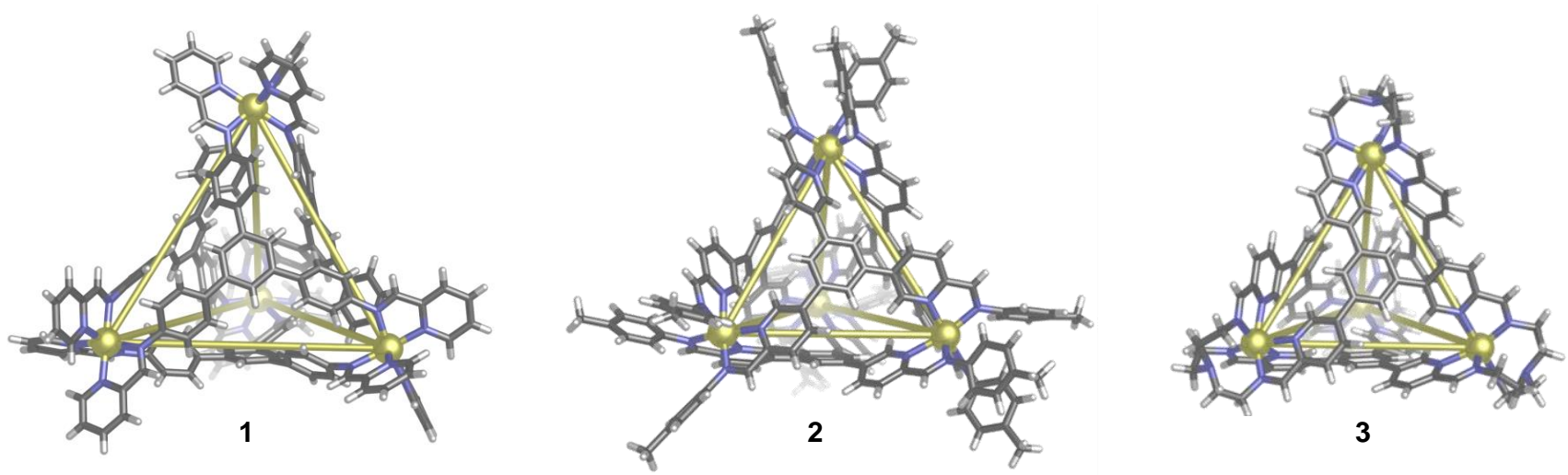

Figure 1. X-ray crystal structures of cages 1, ${ }^{16 c} \mathbf{2}$ and 3. Anions and solvent molecules are omitted for clarity.

Anion-binding strengths were quantified through ${ }^{1} \mathrm{H}$ NMR titrations, and the results are given in Table 1 (see section 2.2 in the SI for experimental details). The affinity of 2 for $\mathrm{SbF}_{6}^{-}$, $\mathrm{ReO}_{4}{ }^{-}$or $\mathrm{TfO}^{-}$was found to be too high for an accurate direct determination of their $K_{\mathrm{a}}$ values, which were instead derived through competitive binding experiments: titration of $\mathrm{SbF}_{6}{ }^{-}$ and $\mathrm{TfO}^{-}$against $\mathrm{PF}_{6}^{-} \subset 2$ and titration of $\mathrm{ReO}_{4}^{-}$against $\mathrm{TfO}^{-}$ $\subset 2$ (Figure 2).
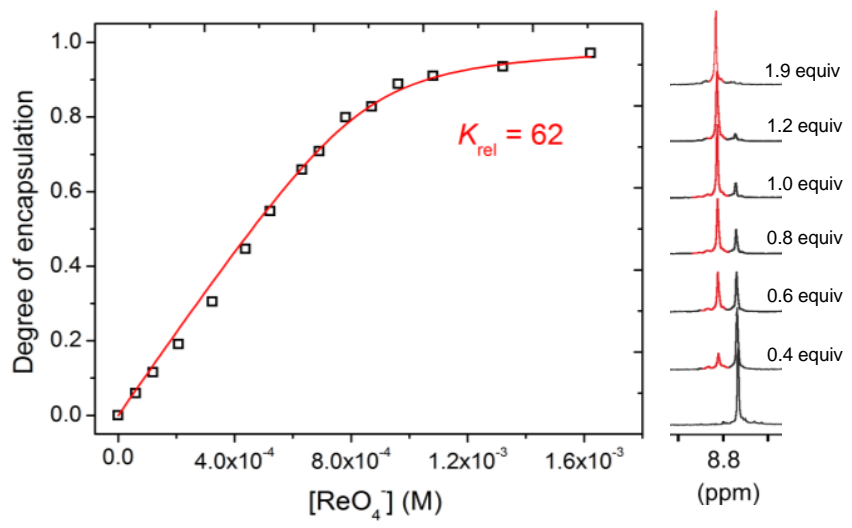

Figure 2. Left: Curve fit for the ${ }^{1} \mathrm{H}$ NMR titration of $\mathrm{ReO}_{4}{ }^{-}$into a solution of $\mathrm{TfO}^{-} \subset \mathbf{2}$ in $\mathrm{CD}_{3} \mathrm{CN}$ to a competitive binding model. ${ }^{10 \mathrm{a}}$ Right: Imine region of selected ${ }^{1} \mathrm{H}$ NMR spectra showing formation of $\mathrm{ReO}_{4}^{-} \subset \mathbf{2}$ (red) and consumption of $\mathrm{TfO}^{-} \subset \mathbf{2}$ (black) upon addition of increasing amounts of $\mathrm{ReO}_{4}^{-}$. See Figure S27 for further details on the data fitting.

In combination, these experiments show that cage $\mathbf{2}$ is capable of accommodating in its interior monocharged anions with volumes ranging from 40 to $85 \AA^{3}$ with the following hierarchy: $\mathrm{ReO}_{4}^{-}>\mathrm{SbF}_{6}^{-}>\mathrm{TfO}^{-}>\mathrm{PF}_{6}^{-} \approx \mathrm{NO}_{3}^{-}>\mathrm{ClO}_{4}^{-}>\mathrm{BF}_{4}{ }^{-}$

. These relative affinities deviate from what would be predicted from Rebek's $55 \%$ occupancy optimum. ${ }^{24,25} \mathrm{We}$ infer that a subtle interplay of size and shape complementarities between host cavity and guest, solvation effects and electrostatic interactions determine together the observed hierarchy, with no single factor predominating. ${ }^{20,26}$ Within a series of anions with the same geometry, larger anions are more strongly bound, such as $\mathrm{ReO}_{4}^{-}$and $\mathrm{SbF}_{6}^{-}$. Despite $\mathrm{TfO}^{-}$and $\mathrm{SbF}_{6}^{-}$having the same molecular volume (Table 1), we infer the better symmetry match between octahedral $\mathrm{SbF}_{6}^{-}$and the tetrahedral cavity renders it a better guest. The high association constant determined for the trigonal planar $\mathrm{NO}_{3}{ }^{-}$, five times greater than that of the larger tetrahedral $\mathrm{ClO}_{4}^{-}$, may be attributed to the lower hydrophobicity of nitrate. ${ }^{27,20}$

Table 1. Summary of binding constants $\left(K_{\mathrm{a}}\right)$ for anions in cages $\mathbf{2}$ and $\mathbf{3}^{a}$

\begin{tabular}{lccc}
\hline & & \multicolumn{2}{c}{$K_{\mathrm{a}}\left(\mathrm{M}^{-1}\right)^{b} /$ NMR exchange } \\
\hline $\mathrm{Guest}^{c}$ & $V\left(\AA^{3}\right)^{d}$ & $\mathbf{2}$ & $\mathbf{3}$ \\
\hline $\mathrm{NO}_{3}^{-}$ & 40.7 & $1.5( \pm 0.3) \times 10^{4} /$ fast & nonbinding \\
\hline $\mathrm{BF}_{4}^{-}$ & 53.3 & $7.1( \pm 0.2) \times 10^{2} /$ fast & nonbinding \\
\hline $\mathrm{ClO}_{4}^{-}$ & 54.8 & $3.0( \pm 0.2) \times 10^{3} /$ slow & nonbinding \\
\hline $\mathrm{ReO}_{4}^{-}$ & 59.8 & $2.2( \pm 0.4) \times 10^{7} /$ slow & $>10^{5} /$ slow \\
\hline $\mathrm{PF}_{6}^{-}$ & 74.7 & $1.4( \pm 0.1) \times 10^{4} /$ slow & $21 \pm 3^{e} /$ slow \\
\hline $\mathrm{SbF}_{6}{ }^{f}$ & 84.7 & $2.5( \pm 0.6) \times 10^{6} /$ slow & $115 \pm 8^{e} /$ slow \\
\hline $\mathrm{TfO}^{-}$ & 85.0 & $3.6( \pm 0.3) \times 10^{5} /$ slow & $41 \pm 3^{e} /$ no exchange \\
& & & observed
\end{tabular}

${ }^{a}$ Cage 1 does not encapsulate anionic guests. ${ }^{16 c, 17 a}{ }^{b}$ Full details of how $K_{\mathrm{a}}$ values and corresponding errors were calculated are given in the Supporting Information sections 2.2 and 2.3. ${ }^{c}$ Addition of $\mathrm{Cl}^{-}, \mathrm{Br}^{-}$, or $\mathrm{I}^{-}$to solutions of $\mathbf{2}$ or $\mathbf{3}$ induced cage decomposition. ${ }^{d}$ Calculated van der Waals volumes, see the Supporting Information. ${ }^{e}$ Estimated values. ${ }^{f}$ Not observed below $70{ }^{\circ} \mathrm{C}$.

Strikingly, cage $\mathbf{3}$ was found to exhibit substantially different guest binding abilities from cage 2, despite their structural similarities. ${ }^{29}$ The addition of $\mathrm{NO}_{3}^{-}, \mathrm{BF}_{4}^{-}, \mathrm{ClO}_{4}^{-}$, $\mathrm{PF}_{6}^{-}$or $\mathrm{TfO}^{-}$to a solution of $\mathbf{2} \cdot\left[\mathrm{NTf}_{2}\right]_{8}$ in acetonitrile caused only slight $(<0.08 \mathrm{ppm})$ shifts in the ${ }^{1} \mathrm{H}$ NMR spectra, even after equilibration at room temperature for several hours (see Figures S33 and S47), in marked contrast with the behavior of the cage 2 . We attribute these changes to a weak interaction of the anions with the exterior of the cage rather than encapsulation. $^{30}$

Previous work has shown that the incorporation of electronrich or electron-poor aniline residues into the periphery of related $\mathrm{Fe}_{4}^{\mathrm{II}} \mathrm{L}_{6}$ capsules did not affect their anion-binding preferences. ${ }^{10 \mathrm{a}} \mathrm{We}$ had therefore not anticipated that the exchange of $p$-toluidine for the more electron-rich tren, in going from $\mathbf{2}$ to $\mathbf{3}$, would have such an impact on the anionbinding preferences. We reasoned the different behavior of 
cage $\mathbf{3}$ may be attributed to the covalent locking effect of tren preventing partial cage opening during anion exchange (discussed below). ${ }^{18,10 \mathrm{~h}}$

In order to probe whether the failure to observe anion binding within $\mathbf{3}$ is due to a thermodynamic or a kinetic effect, we performed three different sets of experiments followed by NMR, illustrated in Scheme 3. In the first (Scheme 3i), cage 3 was prepared from subcomponents in the presence of different prospective anionic guests. In the second (Scheme 3ii), the fates of anions encapsulated within 2 were charted during the course of a 2 to 3 transformation. In the third (Scheme 3iii), preformed 3. $\left[\mathrm{NTf}_{2}\right]_{8}$ was treated with the same series of anions at $70{ }^{\circ} \mathrm{C}$ during a time course of many days. Cage 3 was observed to bind $\mathrm{ReO}_{4}^{-}, \mathrm{PF}_{6}^{-}, \mathrm{SbF}_{6}^{-}$and $\mathrm{TfO}^{-}$, but not $\mathrm{NO}_{3}{ }^{-}, \mathrm{BF}_{4}{ }_{4}^{-}$, or $\mathrm{ClO}_{4}{ }^{-}$during its formation (Scheme $3 i \& i i$ ); the same set of anions were encapsulated following prolonged heating (Scheme 3iii), with the exception of triflate. Experimental details of anion encapsulation studies are provided in the Supporting Information section 2.3.

Scheme 3. Experiments probing the anion-binding properties of cage 3 . $^{a}$
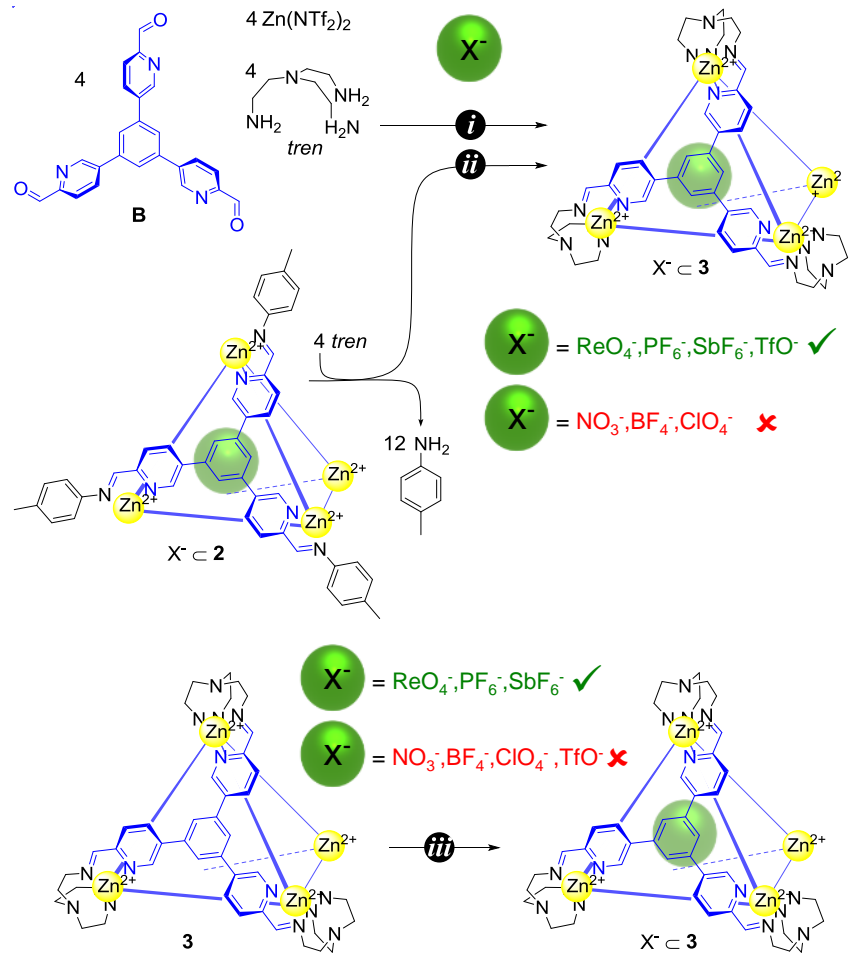

${ }^{a} i$ ) When formed from subcomponents, 3 is observed to encapsulate $\mathrm{ReO}_{4}^{-}, \mathrm{PF}_{6}^{-}, \mathrm{SbF}_{6}^{-}$and $\mathrm{TfO}^{-}$, but not $\mathrm{NO}_{3}^{-}, \mathrm{BF}_{4}^{-}$, or $\mathrm{ClO}_{4}^{-}$; ii) the same anion selectivity was observed during the formation of $\mathbf{3}$ from $\mathbf{2}$; iii) the same anions were observed to be taken up within $\mathbf{3}$ following lengthy equilibration, except triflate.

Binding of perrhenate inside tetrahedron 3 was confirmed by X-ray crystallography (Figure 3 ). The encapsulated $\mathrm{ReO}_{4}$ is located close to the center of the tetrahedral cavity with the oxygen atoms oriented towards the zinc centers. The $\mathrm{Zn}-\mathrm{Zn}$ distances and volume are similar to the empty cage. In addition, the complex $\mathrm{ReO}_{4}{ }^{-} \subset \mathbf{3}$ was found to be stable in water. The nitrate salt of the host-guest complex, although of modest solubility (ca. $0.2 \mathrm{mM}$ ), showed no degradation following $24 \mathrm{~h}$ at room temperature in $\mathrm{D}_{2} \mathrm{O}$ (Figure $\mathrm{S} 41$ ).

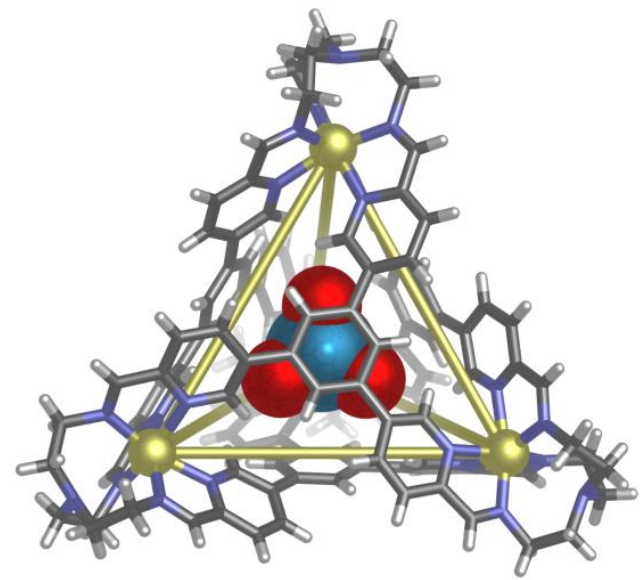

Figure 3. The crystal structure of $\mathrm{ReO}_{4}{ }^{-} \subset 3$. Only one of the two crystallographically distinct cages is shown. The encapsulated $\mathrm{ReO}_{4}{ }^{-}$is shown in space-filling mode and non-encapsulated anions are omitted for clarity.

The slow uptake of anions into tetrahedron $\mathbf{3}$ prevented determination of their association constants through titration experiments. The binding strengths of $\mathrm{PF}_{6}^{-}, \mathrm{SbF}_{6}{ }^{-}$and $\mathrm{TfO}$ were estimated by measuring the relative integration of signals due to free and bound host in the ${ }^{1} \mathrm{H}$ NMR spectra of samples following the transformation of $\mathbf{2}$ into $\mathbf{3}$ in the presence of an excess of the selected anion (Table 1). The binding of $\mathrm{ReO}_{4}^{-}$to 3 was found to be too strong for estimation of its association constant by this method, but a lower limit of $10^{5} \mathrm{M}^{-1}$ could be obtained by NMR (see Supporting Information section 2.3.3).

In summary, with the exception of $\mathrm{BF}_{4}^{-}, \mathrm{NO}_{3}{ }^{-}$and $\mathrm{ClO}_{4}{ }^{-}$ which have been found to bind only to $\mathbf{2}$, both trisformylpyridine-based $\mathrm{Zn}_{4}{ }_{4} \mathrm{~L}_{4}$ structures $\mathbf{2}$ and $\mathbf{3}$ showed similar trends in anion-binding preferences: $\mathrm{ReO}_{4}{ }^{-}>\mathrm{SbF}_{6}{ }^{-}$ $>\mathrm{TfO}^{-}>\mathrm{PF}_{6}^{-}$.

The quantification of anion-binding strengths revealed an outstanding selectivity of cages $\mathbf{2}$ and $\mathbf{3}$ for $\mathrm{ReO}_{4}^{-}$. Cage $\mathbf{2}$ has 10 and 60 times greater affinity for $\mathrm{ReO}_{4}{ }^{-}$than for $\mathrm{SbF}_{6}{ }^{-}$or $\mathrm{TfO}^{-}$, respectively, the next most strongly bound anions (Table 1). As discussed above, this is likely due to a combination of symmetry match between host and guest and optimal volume occupation ratio. To the best of our knowledge, cage 2 represents the strongest $1: 1$ perrhenate binding host $\left(K_{\mathrm{a}}=\right.$ $2.2 \pm 0.4 \times 10^{7} \mathrm{M}^{-1}$ ) reported to date in either organic or aqueous media. ${ }^{19,21}$ The combination of water stability and exceptional affinity for $\mathrm{ReO}_{4}^{-}$suggests that 3 might show promise in pertechnetate binding, of relevance in the context of radiopharmaceuticals and nuclear waste treatment, as discussed in the Supporting Information section 2.3.4. ${ }^{19,20,21 c, 28}$

Kinetics and mechanism of anion uptake. Despite showing similar anion binding preferences, very different guest exchange kinetics were observed for cages $\mathbf{2}$ and $\mathbf{3}$. This observation led us to carry out a brief kinetic study, the results of which shed light upon the mechanisms of guest exchange. The smallest anions, $\mathrm{NO}_{3}^{-}$and $\mathrm{BF}_{4}^{-}$, exchanged between free and encapsulated states within $\mathbf{2}$ at a rate more rapid than the 
NMR time scale. We estimate a lower limit of $30 \mathrm{~s}^{-1}$, considering a difference of about $27 \mathrm{~Hz}$ between ${ }^{1} \mathrm{H}$ NMR resonances of the empty and guest-containing cage. ${ }^{31}$ The guest exchange kinetics of $\mathrm{ClO}_{4}^{-}$were examined by ${ }^{1} \mathrm{H}-{ }^{1} \mathrm{H}$ exchange spectroscopy (EXSY) NMR, ${ }^{22 b, 32,33}$ providing an uptake rate constant $\left(k_{\text {in }}\right)$ of $(3.0 \pm 0.5) \times 10^{3} \mathrm{M}^{-1} \mathrm{~s}^{-1}$, at $25^{\circ} \mathrm{C}$. Rate constants for the guest exchange of $\mathrm{ReO}_{4}^{-}, \mathrm{PF}_{6}^{-}, \mathrm{SbF}_{6}^{-}$ and $\mathrm{TfO}^{-}$could not be determined by EXSY because the uptake rates were too slow for the timescale of this technique (even at $70^{\circ} \mathrm{C}$ ), but also too fast to be followed by ${ }^{1} \mathrm{H}$ NMR: in all cases the system had already reached equilibrium by the time the first ${ }^{1} \mathrm{H}$ NMR spectrum could be acquired following addition of anion to the cage solution. Considering the timescale of the EXSY experiment, we infer the $k_{\text {in }}$ values for these guests to be lower than $10^{3} \mathrm{M}^{-1} \mathrm{~s}^{-1}$ (see Supporting Information section 2.4 and Table S7).

The slower anion uptake rates exhibited by the trencontaining tetrahedron 3 allowed encapsulation to be followed by ${ }^{1} \mathrm{H}$ NMR $\left(\mathrm{PF}_{6}^{-}\right)$or UV-vis $\left(\mathrm{ReO}_{4}^{-}\right)$, following the addition of excess anion to a solution of empty cage under pseudo-first order conditions. These experiments were performed at $70{ }^{\circ} \mathrm{C}$ since exchange of $\mathrm{PF}_{6}^{-}$was not observed at lower temperatures. At concentrations suitable for NMR analysis, the addition of any excess of $\mathrm{ReO}_{4}^{-}$to 3 in solution caused precipitation. To circumvent this practical problem we followed $\mathrm{ReO}_{4}^{-}$uptake at lower concentrations by UV-vis. The second-order rate constants $k_{\text {in }}$ for $\mathrm{ReO}_{4}^{-}$and $\mathrm{PF}_{6}^{-}$were determined to be $47 \pm 2 \mathrm{M}^{-1} \mathrm{~s}^{-1}$ and $1.7 \pm 0.4 \times 10^{-3} \mathrm{M}^{-1} \mathrm{~s}^{-1}$, respectively, at $70{ }^{\circ} \mathrm{C}$. The kinetics of inclusion for $\mathrm{SbF}_{6}^{-}$and $\mathrm{TfO}^{-}$into $\mathbf{3}$ could not be determined because of their very slow and non-observed uptakes, respectively (see section 2.4.2 in the SI).

The timescales for anion exchange given in Figure 4 illustrate the large differences in uptake rates between $\mathbf{2}$ and $\mathbf{3}$. The incorporation of chelating tren in $\mathbf{3}$ was observed to slow encapsulation dramatically. Both of the plausible anion uptake mechanisms, diffusion of guest through the structure's portals, or partial disassembly to create transient larger portals, ${ }^{22 \mathrm{~b}}$ are expected to be more energetically costly in cage 3 . The covalent bonds of $\mathbf{3}$ must be distorted or cleaved in order for the cage to open, whereas $\mathbf{2}$ may be opened through the stretching or rupture of weaker coordinative linkages.

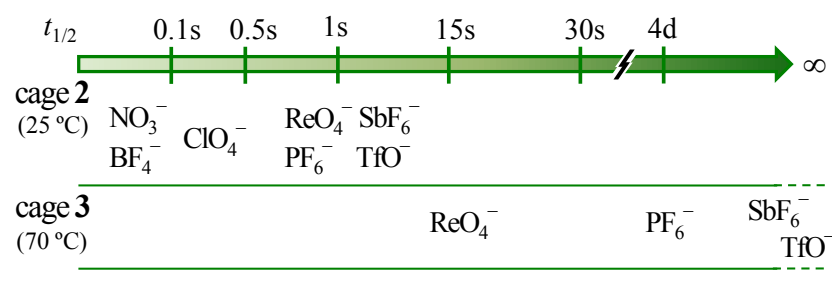

Figure 4. Relative timescales of anion uptake by cages $\mathbf{2}$ and $\mathbf{3}$. Half-lives are based on apparent rate constants at a $1 \mathrm{mM}$ guest concentration. N.B. For $\mathrm{PF}_{6}{ }^{-}$and $\mathbf{3}$, no exchange was observed below $70^{\circ} \mathrm{C}$.

The enclosed and rigid structure of the face-capped tetrahedra 2 - 3, which appeared to leave no access for guest diffusion through the small portals on the edges (Figures S95S96), led us to hypothesize that the exchange of any guest would require $\mathrm{N} \rightarrow \mathrm{Zn}$ bond breakage. The observed marked dependence of anion uptake rates upon the size and shape of the guest, however, suggests that more than one mechanism may be at work. The fast exchange of the smallest anions $\mathrm{BF}_{4}$ and $\mathrm{NO}_{3}{ }^{-}$in and out of cage $\mathbf{2}$ seems unlikely to involve bondbreaking. ${ }^{34}$ We infer that these anions may be undergoing exchange via a through-portal mechanism, whereby the ligands distort sufficiently to allow anion exchange without coordinative bond cleavage. ${ }^{35,15 \mathrm{~b}}$ The slower exchange exhibited by the largest anions $\mathrm{PF}_{6}^{-}, \mathrm{SbF}_{6}^{-}$, and $\mathrm{TfO}^{-}$appears likely to involve partial cage opening and $\mathrm{N} \rightarrow \mathrm{Zn}$ bond rupture, which we infer to incur a considerably higher energetic penalty for cage $3{ }^{22 b}$ Perchlorate, showing an uptake rate intermediate between these two classes of anions, may exchange via a more energetically-costly cage deformation, or partial vertex decoordination, or both. In addition, the higher association constants of $\mathrm{ClO}_{4}^{-}$and $\mathrm{ReO}_{4}^{-}$, having the same shape and slightly larger volumes than $\mathrm{BF}_{4}^{-}$, can also hamper exchange, accounting for why the observed exchange timescale for $\mathrm{ReO}_{4}^{-}$is on the same order as for the larger anions.

Collectively, the insights gained from these anion binding studies enables the design of systems incorporating the responsive behavior of tris-formylpyridine based cages $\mathbf{2}$ and $\mathbf{3}$ and anions: Guest release on treatment of an anion $\subset \mathbf{2}$ complex with an anion with higher affinity and treatment with tren to form 3 (Scheme 3ii) with concomitant guest release $\mathrm{NO}_{3}{ }^{-}$, $\mathrm{BF}_{4}{ }^{-}$and $\left.\mathrm{ClO}_{4}{ }^{-}\right)$or guest trapping in its cavity $\left(\mathrm{ReO}_{4}{ }^{-}, \mathrm{PF}_{6}{ }^{-}\right.$, $\mathrm{SbF}_{6}{ }^{-}$and $\mathrm{TfO}^{-}$).

Neutral guest binding. The ability of tetrahedral cages $\mathbf{1}$ - $\mathbf{3}$ to act as hosts for neutral molecules was also investigated in solution by NMR. To first establish the scope of guest binding we screened a series of neutral molecules, listed in Table 2, selected with different sizes and molecular volumes, distributed around the optimal guest volume for each cage predicted using Rebek's 55\% optimum occupancy rule. ${ }^{24}$ In all cases where host-guest complexes were inferred to form, the ${ }^{1} \mathrm{H}$ NMR spectrum of an equilibrated mixture of an excess of the selected guest and the cage in $\mathrm{CD}_{3} \mathrm{CN}$ showed two sets of host peaks - attributed to empty $\mathrm{Zn}_{4}{ }_{4} \mathrm{~L}_{4}$ and guest $\subset \mathrm{Zn}^{\mathrm{II}}{ }_{4} \mathrm{~L}_{4}$ in slow exchange - and also two sets of signals for the guest assigned to the free and encapsulated guests (Figures S64S80).

Host 1 was reported in a preliminary study to accommodate cyclohexane and $t \mathrm{BuOH}$ within its cavity. ${ }^{16 \mathrm{c}} \mathrm{We}$ screened an extended series of neutral molecules, including those observed to bind inside cage 2 (see below), and also explored their relative binding strengths. The association constant $\left(K_{\mathrm{a}}\right)$ of cyclohexane in 1 was calculated through a ${ }^{1} \mathrm{H}$ NMR titration experiment to be $4.9 \pm 0.3 \times 10^{2} \mathrm{M}^{-1}$. For all other guests, affinities relative to cyclohexane were obtained by NMR on the basis of their ability to displace cyclohexane from the cavity of cage 1 (Supporting Information section 2.5.1). Host 1 was thus revealed to show similar guest-binding abilities to those of its $\mathrm{Fe}^{\mathrm{II}}$ congener, ${ }^{17 \mathrm{a}}$ although $\mathbf{1}$ was able to bind larger guests than the latter, such as cyclooctane and adamantane, due to its larger cavity. ${ }^{17 \mathrm{a}, 16 \mathrm{c}}$ The most strongly bound guests for $\mathbf{1}$ are $\mathrm{CCl}_{4}>$ norbornane > norbornene > cyclopentane > cyclohexane. 
Table 2. Comparison of neutral guest-binding properties of cages 1 and 2.

\begin{tabular}{|c|c|c|c|}
\hline \multirow[b]{2}{*}{ Guest } & \multirow[b]{2}{*}{$V\left(\AA^{3}\right)^{c}$} & \multicolumn{2}{|c|}{$K_{\mathrm{a}}\left(\mathrm{M}^{-1}\right)^{b}$} \\
\hline & & $\mathbf{1}^{d}$ & 2 \\
\hline $\mathrm{CH}_{2} \mathrm{Cl}_{2}$ & 60.9 & $\operatorname{low}^{e}$ & $1.2( \pm 0.2)$ \\
\hline $\mathrm{CHCl}_{3}$ & 74.7 & $1.5( \pm 0.1) \times 10^{2}$ & $11( \pm 0.2)$ \\
\hline $\mathrm{CCl}_{4}$ & 88.7 & $1.2( \pm 0.1) \times 10^{3}$ & $15( \pm 3)$ \\
\hline$t \mathrm{BuOH}$ & 95.4 & low $^{e}$ & $3.5( \pm 0.8)$ \\
\hline cyclopentane & 95.3 & $6.7( \pm 0.4) \times 10^{2}$ & $10( \pm 0.8)$ \\
\hline cyclopentanol & 102.6 & $\operatorname{low}^{e}$ & $6.6( \pm 0.6)$ \\
\hline methylcyclopentane & 113.2 & $1.6( \pm 0.1) \times 10^{2}$ & $2.8( \pm 0.4)$ \\
\hline 1-methylcyclopentanol & 120.5 & $\operatorname{low}^{e}$ & nonbinding \\
\hline cyclohexane & 111.9 & $4.9( \pm 0.1) \times 10^{2 f}$ & nonbinding \\
\hline norbornene & 116.5 & $6.9( \pm 0.4) \times 10^{2}$ & $6.8( \pm 0.3)$ \\
\hline norbornane & 120.2 & $1.1( \pm 0.1) \times 10^{3}$ & $5.2( \pm 0.3)$ \\
\hline 7-bromonorbornane & 138.3 & $49( \pm 3)$ & nonbinding \\
\hline cyclooctane & 146.5 & low $^{e}$ & $g$ \\
\hline benzene & 99.5 & low $^{e}$ & nonbinding \\
\hline 1,3,5-trifluorobenzene & 113.1 & nonbinding & nonbinding \\
\hline $\begin{array}{l}1,3,5- \\
\text { trimethoxybenzene }\end{array}$ & 180.1 & nonbinding & nonbinding \\
\hline naphthalene & 151.0 & nonbinding & nonbinding \\
\hline n-pentane & 106.8 & low $^{e}$ & nonbinding \\
\hline n-hexane & 125.2 & nonbinding & nonbinding \\
\hline adamantane & 159.1 & $59( \pm 4)$ & $g$ \\
\hline 1-bromoadamantane & 177.3 & nonbinding & $g$ \\
\hline
\end{tabular}

${ }^{a}$ Cage 3 showed no evidence for binding neutral guests. ${ }^{b}$ Full details of how $K_{\mathrm{a}}$ values and corresponding errors were calculated are given in Supporting Information section 2.5. ${ }^{c}$ Calculated van der Waals volumes, see the Supporting Information for details. ${ }^{d}$ From $K_{\text {rel }}$ values determined in competitive experiments with cyclohexane. The reported error for each $K_{\mathrm{a}}$ value was estimated by error propagation analysis (see Table $\mathrm{S} 8$ and section 2.5.1). ${ }^{e}$ Binding too weak to displace cyclohexane. ${ }^{f}$ Determined by ${ }^{1} \mathrm{H}$ NMR titration. ${ }^{g}$ Not examined for binding to 2 due to its large size

Host 2 was found to accommodate small hydrophobic molecules with volumes from $61 \AA^{3}$ (dichloromethane) to 120 $\AA^{3}$ (norbornane). Notably, certain molecules, such as benzene, $n$-pentane or cyclohexane, with calculated volumes within the above range, did not bind within 2 , reflecting the necessity of a shape fit. In all cases the measured affinities were too weak to allow for determination of the binding constant via ${ }^{1} \mathrm{H}$ NMR titration. Instead, they were estimated by measuring the relative integration of signals for free and bound host in slow exchange at different guest concentrations (see section 2.5.1 in the Supporting Information). The strongest binders are $\mathrm{CCl}_{4}>$ cyclopentane $>\mathrm{CHCl}_{3}$, suggesting the volume range $75-95 \AA^{3}$ to be optimal for encapsulation within cage 2 .
None of the prospective neutral guests showed evidence for binding to cage 3 , even following heating to $60^{\circ} \mathrm{C}$ for 5 days, or assembly of $\mathbf{3}$ in the presence of excess prospective guest.

Selective guest binding within mixtures. Table 2 provides an overview of the neutral-guest-binding properties of tetrahedra $\mathbf{1}$ and $\mathbf{2}$. From the data presented in Tables $\mathbf{1}$ and $\mathbf{2}$ it is possible to draw the following conclusions: $i$ ) tetrahedra $\mathbf{2}$ and $\mathbf{3}$ encapsulate anions with high affinities; $i$ ) tetrahedron 3 binds a subset of the anions found to bind to 2 , with lower affinities; iii) $\mathbf{2}$ binds weakly a series of neutral molecules with volumes ranging 60-120 $\AA^{3}$; iv) tetrahedron 1 encapsulates a wider range of neutral guests, including all of those observed to bind within $2 ; v$ ) in all cases $\mathbf{1}$ shows a higher affinity than $\mathbf{2}$ for each neutral guest, and for both cages the most strongly bound neutral guest is $\mathrm{CCl}_{4}$. From these observations, several three-guest systems can be selected wherein two of the guests $\left(\mathrm{C}_{6} \mathrm{H}_{12}\right.$ and $\mathrm{CHCl}_{3}$ in Scheme 1) are selectively bound to $\mathbf{1}$ and 2, respectively, in a 1:1 cage mixture, and a third anionic guest $\left(\mathrm{ReO}_{4}{ }^{-}\right.$in Scheme 1) may be added to the mixture in order to selectively trigger the release of the first guest from the cavity of cage $\mathbf{2}$, thus acting as a selective chemical stimulus to the system.

Two sets of guests were selected to demonstrate sequenceselective release from an initial $1: 1$ mixture of $\mathbf{1} \cdot\left[\mathrm{NTf}_{2}\right]_{8}$ and $2 \cdot\left[\mathrm{NTf}_{2}\right]_{8}$ in $\mathrm{CD}_{3} \mathrm{CN}$. The first set of guests, shown in the system of Scheme 1, consists of the two neutral molecules $\mathrm{C}_{6} \mathrm{H}_{12}$ and $\mathrm{CHCl}_{3}$. The ${ }^{1} \mathrm{H} \mathrm{NMR}$ spectrum after addition of $\mathrm{C}_{6} \mathrm{H}_{12}$ and $\mathrm{CHCl}_{3}$ (130 equiv each) showed selective binding of cyclohexane to 1 and of $\mathrm{CHCl}_{3}$ to 2 (Figure S81). The subsequent addition of $\mathrm{ReO}_{4}^{-}$(1.1 equiv) to the mixture showed selective formation of $\mathrm{ReO}_{4}{ }^{-} \subset \mathbf{2}$.

The second set of guests comprises two anions $\left(\mathrm{PF}_{6}^{-}\right.$and $\left.\mathrm{ReO}_{4}{ }^{-}\right)$and a neutral molecule $\left(\mathrm{C}_{6} \mathrm{H}_{12}\right) .{ }^{1} \mathrm{H}$ and ${ }^{19} \mathrm{~F}$ NMR spectra taken of a mixture of 1 ( 1 equiv), 2 (1 equiv), $\mathrm{PF}_{6}^{-}$(1.7 equiv), and $\mathrm{C}_{6} \mathrm{H}_{12}$ (88 equiv), showed exclusive formation of $\mathrm{C}_{6} \mathrm{H}_{12} \subset \mathbf{1}$ and $\mathrm{PF}_{6}{ }^{-} \subset \mathbf{2}$. Subsequent addition of $\mathrm{ReO}_{4}^{-}(1.3$ equiv) displaced $\mathrm{PF}_{6}{ }^{-}$from 2 to form the $\mathrm{ReO}_{4}{ }^{-} \subset \mathbf{2}$ complex (Figure S82).

Reaction of cage mixtures with tren. Next we set out to explore tren as a selective chemical stimulus, taking advantage of the differential reactivity of cages $\mathbf{1}$ and $\mathbf{2}$ towards this triamine. As discussed above, the reaction of cage 2 with tren affords cage 3 . In contrast, tren is observed to induce disassembly of cage 1 by extracting its constituents $\mathrm{Zn}^{\text {II }}$ and 2-formylpyridine to form the mononuclear complex zinc(II) tris(pyridyliminoethyl)amine and release free $\mathbf{A}$ (Figure S86). ${ }^{36}$ Remarkably, the outcome of the reaction of a mixture of $\mathbf{1}$ and $\mathbf{2}$ with tren was observed to be pathway dependent. ${ }^{15 g, 37}$

The addition of tren (4 equiv) to a mixture of 1 and 2 (1:1) in $\mathrm{CD}_{3} \mathrm{CN}$ resulted in the selective disassembly of cage 1 (Figure S83). After $10 \mathrm{~min}$ at $25^{\circ} \mathrm{C}, 60 \%$ of 1 had already been consumed whereas 2 remained intact. After equilibration of this mixture at $60{ }^{\circ} \mathrm{C}$ for $12 \mathrm{~h}$, cage $\mathbf{1}$ had been totally consumed and the mononuclear complex formed (ca. 4 equiv relative to the initial amount of 1). ${ }^{38} \mathrm{~A}$ decrease in the total amount of cage 2 was also observed (ca. $20 \%$ by ${ }^{1} \mathrm{H}$ NMR integration), which we infer to be due to the reaction between liberated $\mathbf{A}$ and $\mathbf{2}$ (as discussed below), yet no signals 
corresponding to cage $\mathbf{3}$ or free $\mathbf{A}$ were identified. Subsequent addition of tren ( 5 equiv) did not result in the expected transformation of $\mathbf{2}$ into $\mathbf{3}$, resulting instead in the formation of insoluble material. Only the mononuclear complex and $p$ toluidine were observed in solution after heating the mixture overnight to $70^{\circ} \mathrm{C}$. We infer the precipitate to result from the reaction of subcomponents $\mathbf{A}$ and $\mathbf{B}$, which are only sparingly soluble in acetonitrile. ${ }^{39}$

In a separate experiment we also tested the reaction of the mixture of $\mathbf{1}$ and $\mathbf{2}$ with excess tren (10 equiv: more than the amount required to break down $\mathbf{1}$ and convert $\mathbf{2}$ into $\mathbf{3}$ ) in a single addition (Figure S84). The ${ }^{1} \mathrm{H}$ NMR spectrum of the mixture after heating to $70{ }^{\circ} \mathrm{C}$ for $12 \mathrm{~h}$ confirmed complete disassembly of $\mathbf{1}$ accompanied by formation of the mononuclear complex and release of $\mathbf{A}$, as well as the formation of cage $\mathbf{3}$ with release of $p$-toluidine, while no precipitate was observed.

This pathway-dependant reaction outcome may be a consequence of the ability of tren to induce the partial disassembly of $\mathbf{2}$ by first extracting the metal template from the structure. Such extraction has been observed to occur during the substitution reaction with tren of $\mathrm{Fe}^{\mathrm{II}}$-containing cages, ${ }_{18}$ and we infer it to be more favorable in a system based on $\mathrm{Zn}^{\mathrm{II}}$, a more labile metal ion. Following the tren-mediated partial disassembly of $\mathbf{2}$, the free tris-aniline $\mathbf{A}$ present in the mixture may interfere with the reaction pathway leading ultimately to the formation of $\mathbf{3}$. We infer the reaction between tris-aniline $\mathbf{A}$ and tris-formylpyridine $\mathbf{B}$ to result in the formation of crosslinked oligomeric material that precipitates, thus removing both subcomponents from solution during the disassembly of cage $\mathbf{2}$ in the presence of $\mathbf{A}$. Indeed, the addition of tren (4.5 equiv) to a solution containing $\mathbf{2}$ and trisaniline $\mathbf{A}$ (4.5 equiv) resulted in precipitation (Figure S87) and not the formation of $\mathbf{3}$. We thus infer this process to occur on the second addition of tren to the cage mixture, once $\mathbf{1}$ has disassembled. A single addition of the amount of tren required to react with both cages in the initial mixture, in contrast, suppresses the formation of insoluble oligomeric material. In this case, we hypothesize that a broader range of more flexible and soluble intermediate products may be generated, in which tren has partially reacted with the frameworks of both $\mathbf{1}$ and $\mathbf{2}$. The excess tren thus serves as a buffer by preventing $\mathbf{A}$ and $\mathbf{B}$ from reacting directly in these intermediate states, thus keeping $\mathbf{B}$ in solution long enough for $\mathbf{3}$ to form.

Control of sequential guest release through orthogonal chemical signals. The studies described above enabled us to devise a system displaying complex stimuli-responsive guest release behavior (Scheme 1). Each step of the sequence was monitored by NMR (Figures 5 and S88 - S91).

Starting from a mixture of $\mathrm{C}_{6} \mathrm{H}_{12} \subset \mathbf{1}, \mathrm{CHCl}_{3} \subset \mathbf{2}$ and 'empty' 2 (1:0.5:0.5), the sequential addition of tren and then $\mathrm{ReO}_{4}{ }^{-}$ brought about the release of cyclohexane and chloroform in that order, as shown in Sequence I of Scheme 1. i) The selective release of cyclohexane upon disassembly of cage $\mathbf{1}$ occurred following the addition of tren ( 4 equiv relative to the total amount of 1) and heating at $60{ }^{\circ} \mathrm{C}$ for 12 hours. This process was tracked by following the disappearance of the ${ }^{1} \mathrm{H}$ NMR resonances corresponding to encapsulated cyclohexane and cage 1 (Figure S88). As described in the analogous experiment in the absence of guests, a small amount of cage 2 had also been consumed (ca. 20\%) after heating. ii) The subsequent addition of $\mathrm{ReO}_{4}^{-}$(1.1 equiv) brought about the complete displacement of $\mathrm{CHCl}_{3}$ from 2 to form the $\mathrm{ReO}_{4}{ }^{-} \subset \mathbf{2}$ inclusion complex after equilibration of the mixture at $70{ }^{\circ} \mathrm{C}$ for $2 \mathrm{~h}$. iii) Finally, the liberation of $\mathrm{ReO}_{4}^{-}$was achieved upon disassembly of $\mathbf{2}$ and precipitation of subcomponents $\mathbf{A}$ and $\mathbf{B}$ on addition of a third signal, tren (4 equiv), to the previous mixture and heating at $70{ }^{\circ} \mathrm{C}$ for $12 \mathrm{~h}$, as confirmed by ${ }^{1} \mathrm{H}$ NMR. $^{40}$
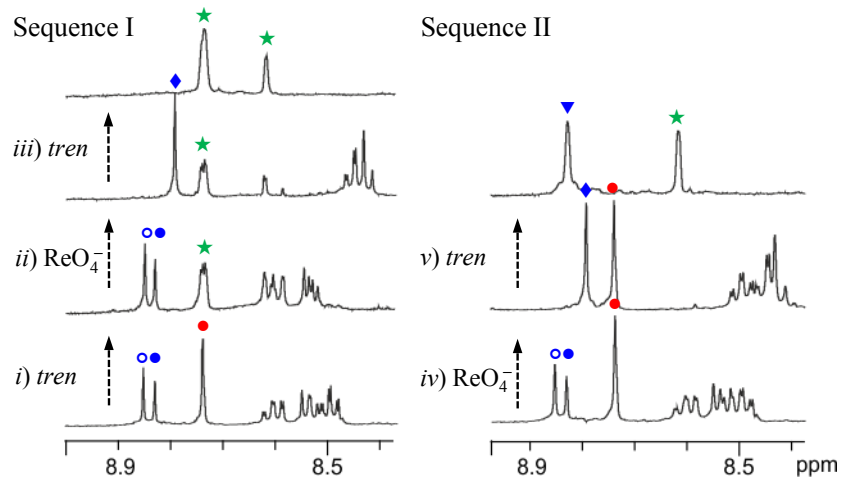

Figure 5. Stacked plots of ${ }^{1} \mathrm{H}$ NMR spectra corresponding to the stimulus/response sequences shown in Scheme 1, starting from a 1:1 mixture of $\mathbf{1}$ and $\mathbf{2}$ selectively encapsulating cyclohexane and chloroform, respectively. Only the imine signals of the different species are labeled as follows: $\bullet=\mathrm{C}_{6} \mathrm{H}_{12} \subset \mathbf{1}, \mathbf{O}=$ 'empty' 2 , $\bullet=\mathrm{CHCl}_{3} \subset \mathbf{2}, \quad \nabla=\mathrm{ReO}_{4}{ }^{-} \subset \mathbf{2}, \quad \boldsymbol{\nabla}=\mathrm{ReO}_{4}{ }^{-} \subset \mathbf{3} \quad$ and $\star=$ mononuclear complexes. Intensities have been scaled for clarity.

When the sequence of signals applied was reversed, so was the order of guests released, as shown in sequence II in Scheme 1.iv) Chloroform was selectively displaced from the cavity of cage 2 following the addition of $\mathrm{ReO}_{4}^{-}$(1.6 equiv) to the starting host-guest system and equilibration of the mixture at $70{ }^{\circ} \mathrm{C}$ for $2 \mathrm{~h}$, as confirmed by ${ }^{1} \mathrm{H}$ NMR (Figures 5 and S89). ii) Addition of tren (10 equiv) to the previous mixture triggered disassembly of cage $\mathbf{1}$, thus releasing cyclohexane, and the transformation of cage $\mathbf{2}$ into $\mathbf{3}$ with concomitant entrapment of $\mathrm{ReO}_{4}{ }^{-}$inside the latter. After equilibration of the sample at $70{ }^{\circ} \mathrm{C}$ for $12 \mathrm{~h}$, the ${ }^{1} \mathrm{H}$ NMR spectrum confirmed formation of mononuclear complexes, disappearance of the resonances due to $\mathrm{C}_{6} \mathrm{H}_{12} \subset \mathbf{1}$, formation of $\mathrm{ReO}_{4}{ }^{-} \subset \mathbf{3}$, and the presence of free $p$-toluidine and tris-aniline $\mathbf{A}$ in solution. The mixture remained soluble throughout the experiment.

Chloroform, cyclohexane and perrhenate were used as a representative guest set. Additionally, we have demonstrated the same orthogonal control over the guest release sequence with $\mathrm{PF}_{6}^{-}$(in place of $\mathrm{CHCl}_{3}$ ), cyclohexane and $\mathrm{ReO}_{4}^{-}$(see Supporting Information section 5.2). Other mixtures are predicted to behave similarly, as long as the first two guests are chosen to bind selectively within $\mathbf{1}$ and $\mathbf{2}$, and the third guest has a higher affinity for $\mathbf{2}$ than its initial guest. Alternatively, in keeping with the differential anion affinities of 2 and 3 , anions such as $\mathrm{BF}_{4}^{-}, \mathrm{NO}_{3}^{-}$or $\mathrm{ClO}_{4}^{-}$, could be incorporated in place of $\mathrm{ReO}_{4}^{-}$in this network, which would result in their release upon transformation of $\mathbf{2}$ into $\mathbf{3}$ in step $v$ ) of Sequence II. 


\section{Conclusions}

The guest binding properties of two new $\mathrm{Zn}^{\mathrm{II}}{ }_{4} \mathrm{~L}_{4}$ tetrahedra based on a tris-formylpyridine subcomponent have been studied in detail. The differing reactivity of tris-formylpyridine and tris-aniline based structures with tren has also been investigated. The insights gained have enabled the design of a chemical system with complex guest encapsulation behavior, in which three guests are individually released in response to distinct chemical signals. As a result, sequence-selective guest release triggered by the specific order of applied stimuli was demonstrated, while the identification of a pathway-dependent reaction of the cage mixture with tren brought about control over the system's overall response, release or capture of the third guest at the end of the sequence.

These findings provide new means for the rational design of more complex systems. Control over the order in which guests are released on demand might be exploited in the development of multi-drug delivery systems, to control the sequential reactivity of multiple catalysts in a reaction mixture, or the release of guests that act as signals to activate subsequent processes. This work thus demonstrates how the study of systems composed of multiple molecular containers with different properties and stimuli-responsive behavior may allow new complex properties and functions, such as pathwaydependent reactivity, to emerge.

Additionally, cage $\mathbf{2}$ was found to be an outstanding host for perrhenate, which can be permanently trapped by in situ transformation into cage $\mathbf{3}$ by the addition of tren. This slow guest exchange kinetics observed for tren containing $\mathbf{3}$ may be relevant for the construction of new more stable capsules for trapping and storage of perrhenate, pertechnetate, or other guests.

\section{ASSOCIATED CONTENT}

\section{Supporting Information}

General synthetic methods, revised synthesis of $\mathbf{B}$, synthesis and characterization of cages $\mathbf{2}$ and $\mathbf{3}$, NMR and ESI-MS spectra, full experimental procedures for the determination of association constants, kinetics of anion uptake studies, selective-sequence guests release experiments and volume calculations and CIF files. This material is available free of charge via the Internet at http://pubs.acs.org. Crystallographic data have also been deposited with the Cambridge Crystallographic Data Centre (entries CCDC 1410005 - 1410007).

\section{AUTHOR INFORMATION}

\section{Corresponding Author}

jrn34@cam.ac.uk

\section{Notes}

The authors declare no competing financial interests.

\section{ACKNOWLEDGMENT}

This work was supported by the European Research Council. We thank Diamond Light Source (UK) for synchrotron beamtime on I19 (MT8464) and Dr. Rana A. Bilbeisi for a preliminary screening of guests for cage $\mathbf{1}$.

\section{REFERENCES}

(1) (a) Ludlow, R. F.; Otto, S. Chem. Soc. Rev. 2008, 37, 101. (b) Mattia, E.; Otto, S. Nature Nanotech. 2015, 10, 111. (c) Lehn, J.-M. Angew. Chem. Int. Ed. 2013, 52, 2836.

(2) (a) del Amo, V.; Philp, D. Chem. - Eur. J. 2010, 16, 13304. (b) Chung, M.-K.; Severin, K.; Lee, S. J.; Waters, M. L.; Gagne, M. R. Chem. Sci. 2011, 2, 744. (c) You, L.; Berman, J. S.; Anslyn, E. V. Nature Chem. 2011, 3, 943. (d) Ritson, D.; Sutherland, J. D. Nature Chem. 2012, 4, 895. (e) Wilson, A.; Gasparini, G.; Matile, S. Chem. Soc. Rev. 2014, 43, 1948. (f) Hsu, C.-W.; Miljanić, O. S̆. Angew. Chem. Int. Ed. 2015, 54, 2219. (g) van der Zwaag, D.; de Greef, T. F. A.; Meijer, E. W. Angew. Chem. Int. Ed. 2015, 54, 2 .

(3) (a) de Ruiter, G.; van der Boom, M. E. Acc. Chem. Res. 2011, 44, 563. (b) Kloxin, C. J.; Bowman, C. N. Chem. Soc. Rev. 2013, 42, 7161. (c) Hu, J.; Liu, S. Acc. Chem. Res. 2014, 47, 2084. (d) Isaacs, L. Acc. Chem. Res. 2014, 47, 2052. (e) Qi, Z.; Schalley, C. A. Acc. Chem. Res. 2014, 47, 2222. (f) Su, X.; Aprahamian, I. Chem. Soc. Rev. 2014, 43, 1963. (g) Wojtecki, R. J.; Meador, M. A.; Rowan, S. J. Nature Mater. 2011, $10,14$. (h) Brioche, J.; Pike, S. J.; Tshepelevitsh, S.; Leito, I.; Morris, G. A.; Webb, S. J.; Clayden, J. J. Am. Chem. Soc. 2015, 137, 6680.

(4) (a) Gianneschi, N. C.; Nguyen, S. T.; Mirkin, C. A. J. Am. Chem. Soc. 2005, 127, 1644. (b) Rodríguez-Llansola, F.; Meijer, E. W. J. Am. Chem. Soc. 2013, 135, 6549. (c) Qian, H.; Aprahamian, I. Chem. Commun. 2015, 51, 11158.

(5) (a) Shaywitz, A.; Greenberg, M. Annu. Rev. Biochem. 1999, 68, 821. (b) Barrell, M. J.; Campaña, A. G.; von Delius, M.; Geertsema, E. M.; Leigh, D. A. Angew. Chem. Int. Ed. 2011, 50, 285. (c) Wang, C.; Li, Z.; Cao, D.; Zhao, Y.-L.; Gaines, J. W.; Bozdemir, O. A.; Ambrogio, M. W.; Frasconi, M.; Botros, Y. Y.; Zink, J. I.; Stoddart, J. F. Angew. Chem. Int. Ed. 2012, 51, 5460. (d) Tian, F.; Jiao, D.; Biedermann, F.; Scherman, O. A. Nat. Commun. 2012, 3, 1207. (e) Xiao, W.; Zeng, X.; Lin, H.; Han, K.; Jia, H.-Z.; Zhang, X.-Z. Chem. Commun. 2015, 51, 1475.

(6) (a) Chen, S.; Itoh, Y.; Masuda, T.; Shimizu, S.; Zhao, J.; Ma, J.; Nakamura, S.; Okuro, K.; Noguchi, H.; Uosaki, K.; Aida, T. Science 2015, 348, 555. (b) Fukino, T.; Joo, H.; Hisada, Y.; Obana, M.; Yamagishi, H.; Hikima, T.; Takata, M.; Fujita, N.; Aida, T. Science 2014, 344, 499. (c) Matson, J. B.; Navon, Y.; Bitton, R.; Stupp, S. I. ACS Macro Letters 2015, 4,43 .

(7) For selected reviews see: (a) Chakrabarty, R.; Mukherjee, P. S.; Stang, P. J. Chem. Rev. 2011, 111, 6810. (b) Ward, M. D. Chem. Commun. 2009, 4487. (c) Jin, P.; Dalgarno, S. J.; Atwood, J. L. Coord. Chem. Rev. 2010, 254, 1760. (d) Harris, K.; Fujita, D.; Fujita, M. Chem. Commun. 2013, 49, 6703. (e) Ronson, T. K.; Zarra, S.; Black, S. P.; Nitschke, J. R. Chem. Commun. 2013, 49, 2476. (f) Han, M.; Engelhard, D. M.; Clever, G. H. Chem. Soc. Rev. 2014, 43, 1848. (g) Mukherjee, S.; Mukherjee, P. S. Chem. Commun. 2014, 50, 2239.

(8) For selected recent examples see: (a) Custelcean, R.; Bonnesen, P. V.; Duncan, N. C.; Zhang, X.; Watson, L. A.; Van Berkel, G.; Parson, W. B.; Hay, B. P. J. Am. Chem. Soc. 2012, 134, 8525. (b) Pasquale, S.; Sattin, S.; Escudero-Adán, E. C.; Martínez-Belmonte, M.; de Mendoza, J. Nat. Commun. 2012, 3, 785. (c) Gütz, C.; Hovorka, R.; Klein, C.; Jiang, Q.-Q.; Bannwarth, C.; Engeser, M.; Schmuck, C.; Assenmacher, W.; Mader, W.; Topić, F.; Rissanen, K.; Grimme, S.; Lützen, A. Angew. Chem. Int. Ed. 2014, 53, 1693. (d) Metherell, A. J.; Ward, M. D. Chem. Commun. 2014 50, 10979. (e) Young, M. C.; Holloway, L. R.; Johnson, A. M.; Hooley, R. J. Angew. Chem. Int. Ed. 2014, 53, 9832. (f) Ramsay, W. J.; Szczypiński, F. T.; Weissman, H.; Ronson, T. K.; Smulders, M. M. J.; Rybtchinski, B.; Nitschke, J. R. Angew. Chem. Int. Ed. 2015, 54, 5636. (g) ThorpGreenwood, F. L.; Kulak, A. N.; Hardie, M. J. Nature Chem. 2015, 7, 526. (h) Wise, M. D.; Holstein, J. J.; Pattison, P.; Besnard, C.; Solari, E.; Scopelliti, R.; Bricogne, G.; Severin, K. Chem. Sci. 2015, 6, 1004.

(9) (a) Cook, T. R.; Vajpayee, V.; Lee, M. H.; Stang, P. J.; Chi, K.-W. Acc. Chem. Res. 2013, 46, 2464. (b) Croue, V.; Goeb, S.; Salle, M. Chem. Commun. 2015, 51, 7275. (c) Therrien, B. Chem. - Eur. J. 2013, 19, 8378. (d) Ward, M. D.; Raithby, P. R. Chem. Soc. Rev. 2013, 42, 1619. (e) Xu, L.; Wang, Y.-X.; Yang, H.-B. Dalton. Trans. 2015, 44, 867. (f) Yoshizawa, M.; Klosterman, J. K.; Fujita, M. Angew. Chem. Int. Ed. 2009, 48, 3418. (g) Brown, C. J.; Toste, F. D.; Bergman, R. G.; Raymond, K. N. Chem. Rev. 2015, 115, 3012.

(10) (a) Hristova, Y. R.; Smulders, M. M. J.; Clegg, J. K.; Breiner, B.; Nitschke, J. R. Chem. Sci. 2011, 2, 638. (b) Neelakandan, P. P.; Jiménez, A.; Nitschke, J. R. Chem. Sci. 2014, 5, 908. (c) Ronson, T. K.; League, A. B.; Gagliardi, L.; Cramer, C. J.; Nitschke, J. R. J. Am. Chem. Soc. 2014, 136, 15615. (d) Turega, S.; Whitehead, M.; Hall, B. R.; Meijer, A. J. H. 
M.; Hunter, C. A.; Ward, M. D. Inorg. Chem. 2013, 52, 1122. (e) Yazaki, K.; Kishi, N.; Akita, M.; Yoshizawa, M. Chem. Commun. 2013, 49, 1630. (f) García-Simón, C.; Garcia-Borràs, M.; Gómez, L.; Garcia-Bosch, I.; Osuna, S.; Swart, M.; Luis, J. M.; Rovira, C.; Almeida, M.; Imaz, I.; Maspoch, D.; Costas, M.; Ribas, X. Chem. - Eur. J. 2013, 19, 1445. (g) García-Simón, C.; Garcia-Borràs, M.; Gómez, L.; Parella, T.; Osuna, S.; Juanhuix, J.; Imaz, I.; Maspoch, D.; Costas, M.; Ribas, X. Nat. Commun. 2014, 5, 5557. (h) Frischmann, P. D.; Kunz, V.; Würthner, F. Angew. Chem. 2015, 127, 7393. (i) Takezawa, H.; Akiba, S.; Murase, T.; Fujita, M. J. Am. Chem. Soc. 2015, 137, 7043.

(11) (a) Duriska, M. B.; Neville, S. M.; Lu, J.; Iremonger, S. S.; Boas, J. F.; Kepert, C. J.; Batten, S. R. Angew. Chem. Int. Ed. 2009, 48, 8919. (b) Riddell, I. A.; Smulders, M. M. J.; Clegg, J. K.; Nitschke, J. R. Chem. Commun. 2011, 47, 457.

(12) (a) Horiuchi, S.; Murase, T.; Fujita, M. J. Am. Chem. Soc. 2011, 133, 12445. (b) Nakabayashi, K.; Kawano, M.; Fujita, M. Angew. Chem. Int. Ed. 2005, 44, 5322. (c) Yoshizawa, M.; Kusukawa, T.; Fujita, M.; Yamaguchi, K. J. Am. Chem. Soc. 2000, 122, 6311.

(13) (a) Hastings, C. J.; Pluth, M. D.; Bergman, R. G.; Raymond, K. N. J. Am. Chem. Soc. 2010, 132, 6938. (b) Jiao, Y.; Wang, J.; Wu, P.; Zhao, L.; He, C.; Zhang, J.; Duan, C. Chem. - Eur. J. 2014, 20, 2224. (c) Murase, T.; Horiuchi, S.; Fujita, M. J. Am. Chem. Soc. 2010, 132, 2866. (d) Otte, M.; Kuijpers, P. F.; Troeppner, O.; Ivanović-Burmazović, I.; Reek, J. N. H.; de Bruin, B. Chem. - Eur. J. 2013, 19, 10170. (e) Samanta, D.; Mukherjee, S.; Patil, Y. P.; Mukherjee, P. S. Chem. - Eur. J. 2012, 18, 12322. (f) García-Simón, C.; Gramage-Doria, R.; Raoufmoghaddam, S.; Parella, T.; Costas, M.; Ribas, X.; Reek, J. N. H. J. Am. Chem. Soc. 2015, $137,2680$.

(14) (a) Zarra, S.; Wood, D. M.; Roberts, D. A.; Nitschke, J. R. Chem. Soc. Rev. 2015, 44, 419. (b) Northrop, B. H.; Zheng, Y.-R.; Chi, K.-W.; Stang, P. J. Acc. Chem. Res. 2009, 42, 1554. (c) Meyer-Eppler, G.; Topić, F.; Schnakenburg, G.; Rissanen, K.; Lützen, A. Eur. J. Inorg. Chem. 2014 2014, 2495. (d) Niess, F.; Duplan, V.; Sauvage, J.-P. J. Am. Chem. Soc. 2014, 136, 5876. (e) Johnson, A. M.; Wiley, C. A.; Young, M. C.; Zhang, X.; Lyon, Y.; Julian, R. R.; Hooley, R. J. Angew. Chem. Int. Ed. 2015, 54, 5641.

(15) (a) McConnell, A. J.; Wood, C. S.; Neelakandan, P. P.; Nitschke, J. R. Chem. Rev. 2015, 115, 7729. (b) Clegg, J. K.; Cremers, J.; Hogben, A. J.; Breiner, B.; Smulders, M. M. J.; Thoburn, J. D.; Nitschke, J. R. Chem. Sci. 2013, 4, 68. (c) Han, M.; Michel, R.; He, B.; Chen, Y.-S.; Stalke, D.; John, M.; Clever, G. H. Angew. Chem. Int. Ed. 2013, 52, 1319. (d) Meng, W.; Ronson, T. K.; Clegg, J. K.; Nitschke, J. R. Angew. Chem. Int. Ed. 2013, 52, 1017. (e) Sørensen, A.; Castilla, A. M.; Ronson, T. K.; Pittelkow, M.; Nitschke, J. R. Angew. Chem. Int. Ed. 2013, 52, 11273. (f) Bradberry, S. J.; Savyasachi, A. J.; Martinez-Calvo, M.; Gunnlaugsson, T. Coord. Chem. Rev. 2014, 273-274, 226. (g) Riddell, I. A.; Ronson, T. K.; Clegg, J. K.; Wood, C. S.; Bilbeisi, R. A.; Nitschke, J. R. J. Am. Chem. Soc. 2014, 136, 9491.

(16) (a) Smulders, M. M. J.; Zarra, S.; Nitschke, J. R. J. Am. Chem. Soc. 2013, 135, 7039. (b) Ma, S.; Smulders, M. M. J.; Hristova, Y. R.; Clegg, J. K.; Ronson, T. K.; Zarra, S.; Nitschke, J. R. J. Am. Chem. Soc. 2013, 135 , 5678. (c) Jiménez, A.; Bilbeisi, R. A.; Ronson, T. K.; Zarra, S.; Woodhead, C.; Nitschke, J. R. Angew. Chem. Int. Ed. 2014, 53, 4556. (d) Cullen, W.; Thomas, K. A.; Hunter, C. A.; Ward, M. D. Chem. Sci. 2015, 6, 4025. (e) Cullen, W.; Turega, S.; Hunter, C. A.; Ward, M. D. Chem. Sci. 2015, 6, 625 .

(17) (a) Bilbeisi, R. A.; Clegg, J. K.; Elgrishi, N.; de Hatten, X.; Devillard, M.; Breiner, B.; Mal, P.; Nitschke, J. R. J. Am. Chem. Soc. 2011, 134, 5110. (b) Caulder, D. L.; Brückner, C.; Powers, R. E.; König, S.; Parac, T. N.; Leary, J. A.; Raymond, K. N. J. Am. Chem. Soc. 2001, 123, 8923. (c) Granzhan, A.; Riis-Johannessen, T.; Scopelliti, R.; Severin, K. Angew. Chem. Int. Ed. 2010, 49, 5515. (d) Saalfrank, R. W.; Glaser, H.; Demleitner, B.; Hampel, F.; Chowdhry, M. M.; Schünemann, V.; Trautwein, A. X.; Vaughan, G. B. M.; Yeh, R.; Davis, A. V.; Raymond, K. N. Chem. - Eur. J. 2002, 8, 493. (e) Albrecht, M.; Shang, Y.; Rhyssen, T.; Stubenrauch, J.; Winkler, H. D. F.; Schalley, C. A. Eur. J. Org. Chem. 2012, 2012, 2422.

(18) Castilla, A. M.; Ousaka, N.; Bilbeisi, R. A.; Valeri, E.; Ronson, T. K.; Nitschke, J. R. J. Am. Chem. Soc. 2013, 135, 17999.
(19) Katayev, E. A.; Kolesnikov, G. V.; Sessler, J. L. Chem. Soc. Rev. 2009, 38, 1572, and references therein.

(20) Busschaert, N.; Caltagirone, C.; Van Rossom, W.; Gale, P. A. Chem. Rev. 2015, 115, 8038.

(21) (a) Kolesnikov, G. V.; German, K. E.; Kirakosyan, G.; Tananaev, I. G.; Ustynyuk, Y. A.; Khrustalev, V. N.; Katayev, E. A. Org. Biomol. Chem. 2011, 9, 7358. (b) Rambo, B. M.; Sessler, J. L. Chem. - Eur. J. 2011, 17, 4946. (c) Cao, R.; McCarthy, B. D.; Lippard, S. J. Inorg. Chem. 2011, 50, 9499. (d) Alberto, R.; Bergamaschi, G.; Braband, H.; Fox, T.; Amendola, V. Angew. Chem. Int. Ed. 2012, 51, 9772. (e) Freye, S.; Michel, R.; Stalke, D.; Pawliczek, M.; Frauendorf, H.; Clever, G. H. J. Am. Chem. Soc. 2013, 135, 8476. (f) Kataev, E. A.; Pantos, P.; Karnas, E.; Kolesnikov, G. V.; Tananaev, I. G.; Lynch, V. M.; Sessler, J. L. Supramol. Chem. 2014, 27, 346. (f) Lim, J. Y. C.; Beer, P. D. Chem. Commun. 2015 $51,3686$.

(22) (a) Custelcean, R. Chem. Soc. Rev. 2014, 43, 1813. (b) Pluth, M. D.; Raymond, K. N. Chem. Soc. Rev. 2007, 36, 161.

(23) Kleywegt, G. J.; Jones, T. A. Acta Cryst. 1994, D50, 178.

(24) Mecozzi, S.; Rebek, J. J. Chem. - Eur. J. 1998, 4, 1016.

(25) Charged hosts have previously been observed not to obey Rebek's $55 \%$ optimal-occupancy "rule". See references $8 \mathrm{f}, 15 \mathrm{~b}$ and 22a.

(26) Chifotides, H. T.; Dunbar, K. R. Acc. Chem. Res. 2013, 46, 894

(27) Anion Coordination Chemistry; Wiley-VCH: Weinheim, 2011.

(28) Moyer, B. A.; Custelcean, R.; Hay, B. P.; Sessler, J. L.; BowmanJames, K.; Day, V. W.; Kang, S.-O. Inorg. Chem. 2013, 52, 3473.

(29) See Figure S97 in the Supporting Information for an overlay of the structures $\mathbf{2}$ and $\mathbf{3}$ in the solid state.

(30) Some association in solution between polycationic hosts and anions has been previously described, see for instance: Frantz, R.; Grange, C. S.; Al-Rasbi, N. K.; Ward, M. D.; Lacour, J. Chem. Commun. 2007, 1459.

(31) Sanders, J. K. M.; Hunter, B. K. Modern NMR Spectroscopy: A Guide for Chemists; Oxford University Press: Oxford, UK, 1993.

(32) Pastor, A.; Martínez-Viviente, E. Coord. Chem. Rev. 2008, 252, 2314.

(33) Exchange spectroscopy (2D EXSY) has been applied for studying kinetics of reversible systems that exchange slowly on the chemical shift timescale but fast in the spin-lattice $\left(T_{1}\right)$ relaxation timescale. In practice, exchange processes with rates rate constants between $10^{2}$ and $10^{-2} \mathrm{~s}^{-1}$ can be investigated. For selected examples see references 10d and 16a-b.

(34) Although $\mathrm{Zn}^{\mathrm{II}}$ is a labile metal ion it has been shown that tightly interlocked structures, like these $\mathrm{Zn}_{4}^{\mathrm{II}} \mathrm{L}_{4}$ assemblies with rigid ligands, provide largely increased kinetic stabilities. See: (a) Charbonnière, L. J.; Williams, A. F.; Frey, U.; Merbach, A. E.; Kamalaprija, P.; Schaad, O. J. Am. Chem. Soc. 1997, 119, 2488. (b) Paul, R. L.; Bell, Z. R.; Jeffery, J. C.; Harding, L. P.; McCleverty, J. A.; Ward, M. D. Polyhedron 2003, 22, 781.

(35) (a) Davis, A. V.; Raymond, K. N. J. Am. Chem. Soc. 2005, 127, 7912. (b) Davis, A. V.; Fiedler, D.; Seeber, G.; Zahl, A.; van Eldik, R.; Raymond, K. N. J. Am. Chem. Soc. 2006, 128, 1324.

(36) Mal, P.; Schultz, D.; Beyeh, K.; Rissanen, K.; Nitschke, J. R. Angew. Chem. Int. Ed. 2008, 47, 8297.

(37) Chepelin, O.; Ujma, J.; Barran, P. E.; Lusby, P. J. Angew. Chem. Int. Ed. 2012, 51, 4194

(38) Formation of two different $\mathrm{Zn}^{\mathrm{II}}$ mononuclear complexes was observed by ${ }^{1} \mathrm{H}$ NMR: the octahedral complex zinc(II) tris(pyridyliminoethyl)amine (Scheme 1) and a zinc(II) trigonal bipyramidal complex where the ligand is formed from the condensation of tren with only 1 equiv of 2-formylpyridine. See Figure S85 in the Supporting Information for details.

(39) $\mathbf{B}$ is insoluble in acetonitrile whereas $\mathbf{A}$ is soluble enough to be observed by ${ }^{1} \mathrm{H}$ NMR at the concentrations used in this work. In experiments not resulting in precipitation, NMR signals due to free $\mathbf{A}$ were observed with integrals matching the concentration of $\mathbf{1}$ in the initial mixture.

(40) Formation of the complex $\mathrm{ReO}_{4}{ }^{-} \subset \mathbf{2}$ was observed upon addition of $2 \cdot\left[\mathrm{NTf}_{2}\right]_{8}$ to the final reaction mixture generated from sequence I (after removal of the precipitate by filtration), thus confirming $\mathrm{ReO}_{4}{ }^{-}$remains in solution. See Figures S88 and S91 in the Supporting Information. 


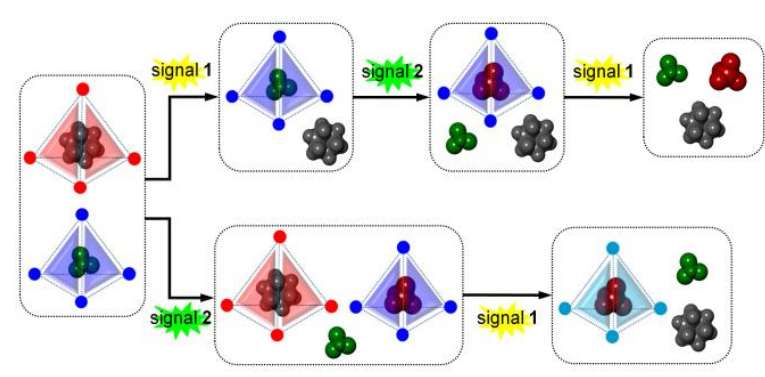

